\title{
Porphyromonas gingivalis Accelerates Neointimal Formation after Arterial Injury
}

\author{
Naho Kobayashi ${ }^{a}$ Jun-ichi Suzuki ${ }^{b, d}$ Masahito Ogawab, d Norio Aoyama ${ }^{a}$ \\ Tomoya Hanatani $^{a}$ Yasunobu Hirata ${ }^{b}$ Ryozo Nagai ${ }^{b}$ Yuichi Izumi ${ }^{a, c}$ \\ Mitsuaki Isobe ${ }^{b}$ \\ ${ }^{a}$ Department of Periodontology, Graduate School of Medical and Dental Sciences, ${ }^{b}$ Department of Cardiovascular \\ Medicine, and ${ }^{\mathrm{C}}$ Global Center of Excellence Program, International Research Center for Molecular Science in Tooth and \\ Bone Diseases, Tokyo Medical and Dental University, and ${ }^{\mathrm{d}}$ Department of Advanced Clinical Science and Therapeutics, \\ University of Tokyo, Tokyo, Japan
}

\section{Key Words}

Porphyromonas gingivalis • Neointima • Matrix

metalloproteinases · Arterial injury

\begin{abstract}
Background: Inflammation plays a key role in neointimal hyperplasia after an arterial injury. Chronic infectious disorders, such as periodontitis, are associated with an increased risk of cardiovascular diseases. However, the effects of a periodontal infection on vascular remodeling have not been examined. We assess the hypothesis that periodontal infection could promote neointimal formation after an arterial injury. Methods: Mice were implanted with subcutaneous chambers ( $n=41$ ). Two weeks after implantation, the femoral arteries were injured, and Porphyromonas gingivalis $(n=21)$ or phosphate-buffered saline $(n=20)$ was injected into the chamber. The murine femoral arteries were obtained for the histopathological analysis. The expression level of mRNA in the femoral arteries was analyzed using quantitative reverse transcriptase polymerase chain reaction ( $\mathrm{n}=19-20)$. Results: The intima/media thickness ratio in the $P$. gingivalis infected group was found to be signifi-
\end{abstract}

cantly increased in comparison to the non-infected group. The expression of matrix metalloproteinase-2 mRNA was significantly increased in the $P$. gingivalis infected group compared to the non-infected group. Conclusion: These findings demonstrate that $P$. gingivalis injection can promote neointimal formation after an arterial injury. Periodontitis may be a critical factor in the development of restenosis after arterial intervention.

Copyright $\odot 2012$ S. Karger AG, Basel

\section{Introduction}

Periodontal disease is a chronic inflammatory disease of the periodontium that leads to erosion of the attachment apparatus and supporting bone of the teeth. It is one of the most common chronic infectious diseases in humans [1]. Cardiovascular disease (CVD) is a common cause of death in industrialized countries. It has been suggested that periodontal disease is associated with an increased risk of CVD [2], and a metaanalysis of epidemiological studies also revealed that there is an association between periodontal disease and

\section{KARGER}

Fax +41613061234 E-Mail karger@karger.ch www.karger.com
(C) 2012 S. Karger AG, Basel $1018-1172 / 12 / 0495-0417 \$ 38.00 / 0$

Accessible online at: www.karger.com/jvr
Dr. Jun-ichi Suzuki

Department of Advanced Clinical Science and Therapeutics

University of Tokyo, Graduate School of Medicine

7-3-1 Hongo, Bunkyo-ku, Tokyo 113-8655 (Japan)

Tel. +81 35800 9116, E-Mail junichisuzuki-circ@umin.ac.jp 
CVD [3]. Several studies have demonstrated that the presence of oral bacteria in atherosclerotic plaques is implicated in the pathogenesis of CVD, and that atherosclerosis and CVD are both accelerated by periodontal disease $[4,5]$.

Severe generalized periodontitis causes a chronic systemic inflammatory response and changes in serum cholesterol and systolic blood pressure [6]. The patients with bacteremia after dental extraction [7, 8], dental scaling [9] and endodontic treatment $[10,11]$ were studied by means of lysis filtration of blood samples, with subsequent aerobic and anaerobic incubation. Recent evidence suggests that periodontal disease may play a significant role in the process of atherosclerosis [12], and DNA from Porphyromonas gingivalis, a major periodontal pathogen, has been detected in carotid atherosclerotic plaques [4] and atherosclerotic vessels [5]. Periodontal pathogens, which are present in atherosclerotic plaques, may play a role in the development and progression of atherosclerosis, leading to CVD $[1,4,13]$.

Balloon angioplasty and stent implantation are the most widely used techniques for treating coronary artery stenosis. However, mechanical injury to the vascular lumen occurs during angioplasty and causes neointimal hyperplasia and vascular remodeling, thus often resulting in restenosis of the culprit lesion [14]. Although the pathogenic mechanism has not been completely resolved, an accumulating body of evidence suggests that the inflammatory response plays a key role in these processes.

Matrix metalloproteinases (MMPs) have been suggested to affect the chemotaxis of inflammatory cells through multiple mechanisms [15]. Many CVDs, such as myocardial infarction [16, 17], atherosclerosis [18] and arteriosclerosis $[19,20]$, involve the upregulation of MMPs by inflammatory cells and vascular smooth muscle cells. In addition, the activation of MMPs predicts the progression of vascular remodeling [21]. We hypothesized that $P$. gingivalis infection would contribute to the development of neointimal hyperplasia after percutaneous coronary intervention. Our laboratory previously demonstrated that infection with $P$. gingivalis could accelerate the progression of experimental abdominal aortic aneurysm by increasing the expression of MMP-2 [22]. The purpose of the present study was to analyze the expression of MMP2 and other factors following $P$. gingivalis infection and to examine the impact of the infection on neointimal formation after an arterial injury.

\section{Material and Methods}

Animals and Study Protocol

Male mice (C57BL/6, aged 7 weeks, 20-25 g) were obtained from Japan Clea Co., Tokyo, Japan, for this study. The experimental procedures described were approved by the Animal Welfare Committee and performed in accordance with the Animal Care Standards of Tokyo Medical and Dental University.

\section{Bacterial Preparation}

P. gingivalis, strain ATCC A7A1-28, was cultivated on blood agar plates in an anaerobic chamber with $85 \% \mathrm{~N}_{2}, 5 \% \mathrm{H}_{2}, 10 \%$ $\mathrm{CO}_{2}$. After incubation at $37^{\circ} \mathrm{C}$ for $2-3$ days, the bacterial cells were inoculated into a peptone yeast extract and incubated for another week. The bacterial concentration was standardized to $10^{8}$ colony-forming units $/ \mathrm{ml}$.

\section{Chamber Model}

Coil-shaped subcutaneous chambers were prepared from 0.5 $\mathrm{mm}$ stainless-steel wire and surgically implanted into the subcutaneous tissue of the back region of each mouse $(n=41)$. Fourteen days elapsed before the chambers were inoculated with $P$. gingivalis $(\mathrm{n}=21)$. During this period, the outer incision healed completely, and the chambers became encapsulated by a thin vascularized layer of fibrous connective tissue. The chambers gradually filled with approximately $0.5 \mathrm{ml}$ of light-colored transudate. Fourteen days after implantation, mice were inoculated with a $0.1-\mathrm{ml}$ suspension of $P$. gingivalis in phosphate-buffered salinePBS. The non-infected group was inoculated with phosphatebuffered saline only $(n=20)$. Mice were sacrificed 7 or 14 days after arterial injury, and the plasma was separated from blood obtained from an orbita plexus venosus puncture.

\section{Wire Injury Model}

In this study, we developed a modified arterial injury model [23]. Briefly, the femoral artery was looped and tied off with 6-0 silk sutures for temporary vascular control during the procedure. A transverse arteriotomy was made, and a flexible angioplasty guidewire was introduced and advanced $1 \mathrm{~cm}$. Endothelial denudation injury of the artery was achieved by wire withdrawal injury [24].

Mice were divided into 2 groups; injured via arterial surgery and inoculated with live $P$. gingivalis $\left(0.1 \mathrm{ml}\right.$ of $10^{8}$ colony-forming units $/ \mathrm{ml}$ ) or injured via arterial surgery and inoculated with vehicle-containing diluted medium $(0.1 \mathrm{ml})$. The subcutaneous injections were performed once per week for 14 days. Fourteen days later, the mice underwent laparotomy and dissection [25]. Figure 1 shows the time schedule of this study.

\section{Histological and Morphometrical Analyses}

The histopathological analyses were performed as described previously [19]. The sections were stained with Elastica van Gieson (EvG). Complete transverse sections of arteries approximately $3 \mathrm{~mm}$ in length were obtained [24]. The persons who selected and measured the histological sections were blinded for the intervention. The thickness of the intima, media and lumen within a cross-section of the artery in the slides stained with EvG were calculated using the Image-Pro Express software program (Media Cybernetics, Silver Spring, Md., USA; $\mathrm{n}=11$ in both groups). We measured the neointimal and medial areas of at least 6 sections 
per artery. We excluded samples from the statistical analysis when they included massive thrombus formation.

\section{Immunohistochemistry}

For immunohistochemical staining, an anti-monocyte chemoattractant protein-1 (MCP-1) antibody and anti-MMP-2 antibody, both from Santa Cruz Biotechnology (Santa Cruz, Calif., USA), were used $(n=3-5)$. Immunohistochemical staining was quantified and investigators were blinded to the treatments of animals.

Real-Time Reverse Transcription Polymerase Chain Reaction

Reverse transcription polymerase chain reaction (RT-PCR) was used to determine the messenger ribonucleic acid (mRNA) expression of MCP-1 (assay ID: Mm00441242_m1; Applied Biosystems, Tokyo, Japan), MMP-2 (assay ID: Mm0043948_m1), MMP-3 (assay ID: Mm00440295_m1), MMP-9 (assay ID: Mm00600163_m1), tissue inhibitor of metalloproteinases-1 (TIMP-1; assay ID: Mm00441818_m1) and TIMP-2 (assay ID: Mm00441825_m1). To account for differences in cDNA preparation and cDNA amplification efficiency, the mRNA expression of the target gene was normalized by $18 \mathrm{~S}$ rRNA. Quantitative data were calculated using the comparative CT $(\Delta \Delta \mathrm{CT})$ method $(\mathrm{n}=$ 19-20) [26].

\section{Detection of $\mathrm{P}$. gingivalis}

Arteries were taken from each group of mice during the bacterial challenge. Total DNA was collected using a QiaAmp kit (Qiagen, Md., USA), and the $P$. gingivalis $16 \mathrm{~S}$ gene was detected by PCR, as described previously ( $\mathrm{n}=3$ in both groups) [27].

\section{Statistical Analysis}

All data are expressed as the mean \pm SEM. The differences between the two groups were analyzed by Student's t test. Differences with $p$ values $<0.05$ were considered to be significant.

\section{Results}

\section{Quantification of Antibacterial Antibodies and \\ Detection of Bacterial DNA}

The effects of the repeated injection of $P$. gingivalis or vehicle on the plasma levels of anti- $P$. gingivalis IgG were determined by ELISA 14 days after injury. As expected, the level of anti- $P$. gingivalis antibodies was significantly increased in the $P$. gingivalis infected mice compared to the non-infected mice. The effects of the repeated injection of $P$. gingivalis or vehicle on the plasma levels of antiP. gingivalis $\operatorname{IgG}$ were determined by ELISA 14 days after injury. As expected, the level of anti- $P$. gingivalis antibodies was significantly increased in the $P$. gingivalis infected mice compared to the non-infected mice. The $P$. gingivalis IgG level of the non-infected group was $0.17 \pm 0.05$ $(\mathrm{n}=6)$. The $P$. gingivalis IgG level of the infected group was $1.10 \pm 0.20(n=6 ; p<0.05$; fig. 2$)$. The systemic pres-

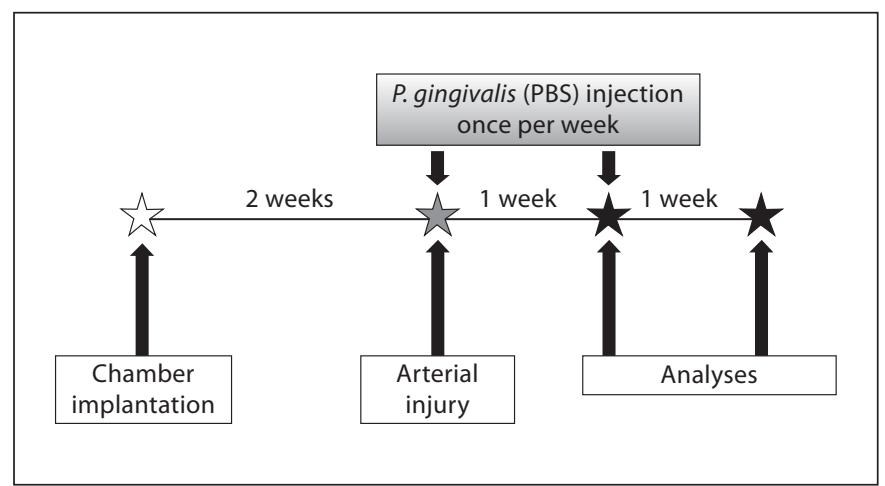

Fig. 1. Time schedule. Live $P$. gingivalis was injected on days 0 and 7 after arterial injury. Samples were collected on days 7 and 14 after arterial injury.

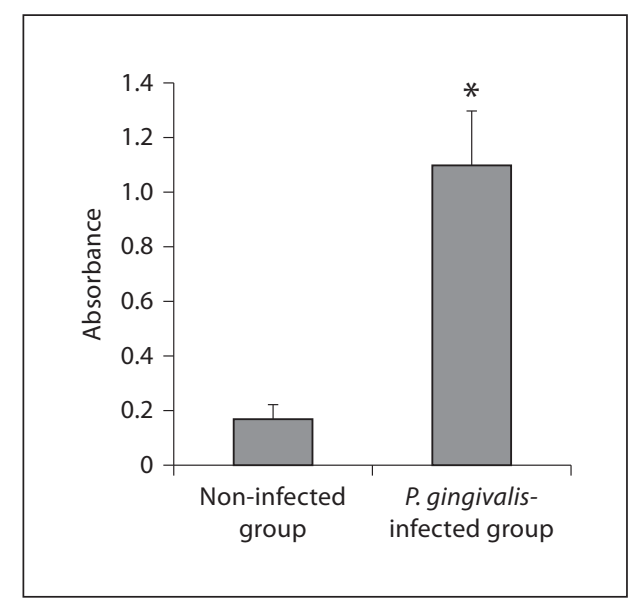

Fig. 2. Levels of anti-P. gingivalis IgG. The effects of repeated injection of $P$. gingivalis or vehicle on the plasma levels of anti- $P$. gingivalis IgG were determined. Plasma samples were obtained from the non-infected group and the $P$. gingivalis infected group at 2 weeks after injury. The level of anti- $P$. gingivalis IgG is expressed as the mean \pm SEM. ${ }^{*} \mathrm{p}<0.05$, significant difference compared to the non-infected group.

sure and heart rate of the mice did not significantly change 2 weeks after arterial injury in both the non-infected and the infected group (data not shown).

P. gingivalis $16 \mathrm{~S}$ DNA was not detected in any of the samples from the injured arteries of any of the mice 14 days after injury ( $\mathrm{n}=3$ in both groups, data not shown).

\section{Quantitative Analysis of Intimal and Medial}

Thickening after Wire Injury

The areas of the vascular wall component were quantitatively analyzed in the arteries of the non-infected and 

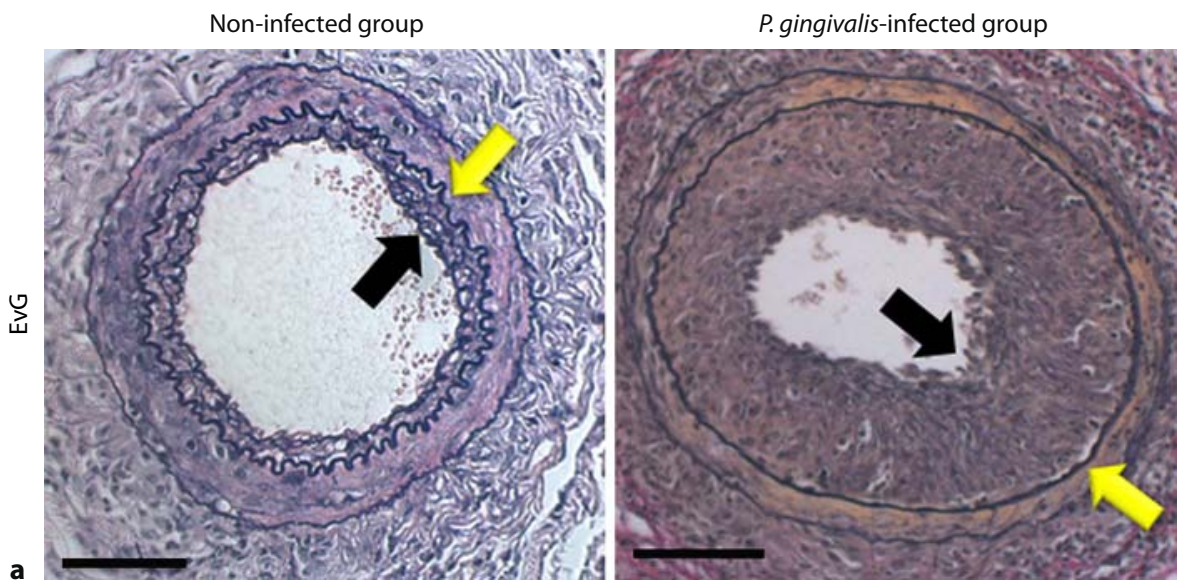

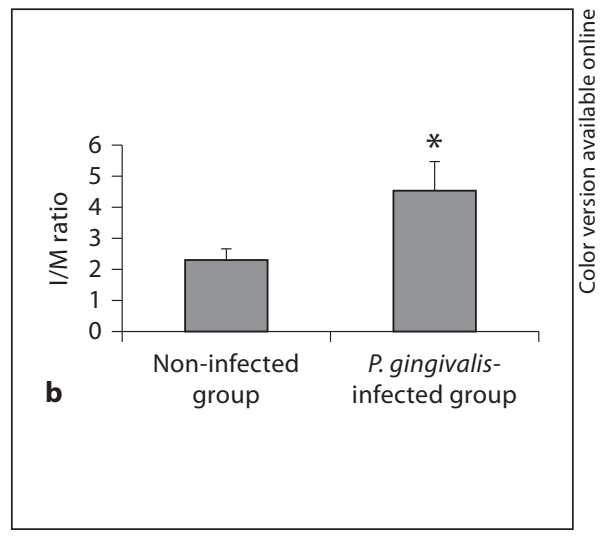

Fig. 3. Intima/media thickness. a EvG-stained sections showing an artery from a non-infected mouse and from a $P$. gingivalis infected mouse, respectively. The black arrows point to the endothelium, and the yellow arrows point to the inner elastic lamina. Histopathological analysis revealed that the neointimal formation of the $P$. gingivalis infected group was enhanced compared to the non-infected group. Scale bars $=50 \mu \mathrm{m}$. The colors refer to the online version of the figure. $\mathbf{b}$ Quantitative intima/media thickness. Representative microscopic findings with EvG staining and the quantitative results are shown. Injured arteries harvested from the non-infected and $P$. gingivalis infected groups both showed thickened intima. However, the $P$. gingivalis infected group showed enhanced intimal thickening compared to the noninfected group. The intima/media (I/M) thickness ratio was 4.54 \pm 0.94 for the $P$. gingivalis infected group $(\mathrm{n}=11)$ and $2.31 \pm 0.35$ for the non-infected group $(\mathrm{n}=11)$. Results are expressed as the mean \pm SEM. ${ }^{*} \mathrm{p}<0.05$.
P. gingivalis infected mice 14 days after injury. In all of the vascular wall sections, the internal and external elastic laminae were identifiable by EvG staining. The histopathological analysis revealed that the intima/media thickness ratio in the P. gingivalis infected group (4.54 \pm $0.94 ; \mathrm{n}=11)$ was significantly increased in comparison to the non-infected group $(2.31 \pm 0.35 ; \mathrm{n}=11 ; \mathrm{p}<0.05)$ (fig. 3). This result suggested that $P$. gingivalis infection promoted neointimal hyperplasia. The uninjured arteries did not change the structure of the artery in both the non-infected and the infected group (data not shown).

\section{Immunohistochemistry}

The $P$. gingivalis infected group $(29.0 \pm 8.80 ; \mathrm{n}=5)$ showed more MCP-1-positive cells in the neointimal area compared to the non-infected group $(4.6 \pm 1.86 ; \mathrm{n}=5$; $\mathrm{p}<0.05) 14$ days after injury (fig. $4 \mathrm{a}, \mathrm{b})$. Moreover, the $P$. gingivalis infected group $(63.8 \pm 19.1 ; \mathrm{n}=4)$ showed a significant increase in the number of MMP-2-positive cells in the adventitial area compared to the non-infected group $(5.3 \pm 2.1 ; \mathrm{n}=3 ; \mathrm{p}<0.05) 14$ days after injury (fig. 4c, d).

\section{Reverse Transcription PCR}

The arteries from the $P$. gingivalis infected group showed significantly increased levels of MMP-2, MMP-3 and TIMP-1 mRNA compared to the arteries from the non-infected group on day 7 after injury (fig. 5). However, there were no significant differences in the MCP-1, MMP-9 or TIMP-2 mRNA levels in the arteries of the $P$. gingivalis infected and the non-infected group (fig. 5).

\section{Discussion}

Periodontitis has been implicated as a risk factor for various systemic diseases. Many researchers have shown that periodontal pathogens contributed to the pathogenesis of peripheral artery diseases. For example, Li et al. [28] reported that oral infection with $P$. gingivalis accelerated early atherosclerosis in apolipoprotein E knockout mice, whereas no lesions were seen in wild-type mice with $P$. gingivalis infections. However, there have been limited studies on whether oral pathogens deteriorate the development of vascular diseases [29].

The present study was based on the hypothesis that distant subcutaneous challenge with live $P$. gingivalis would contribute to the development of neointimal hyperplasia in mice after wire injury of femoral arteries. We used a model of localized distant infection by means of a subcutaneous chamber, which was previously shown to mimic the sequence of localized inflammatory events ob- 

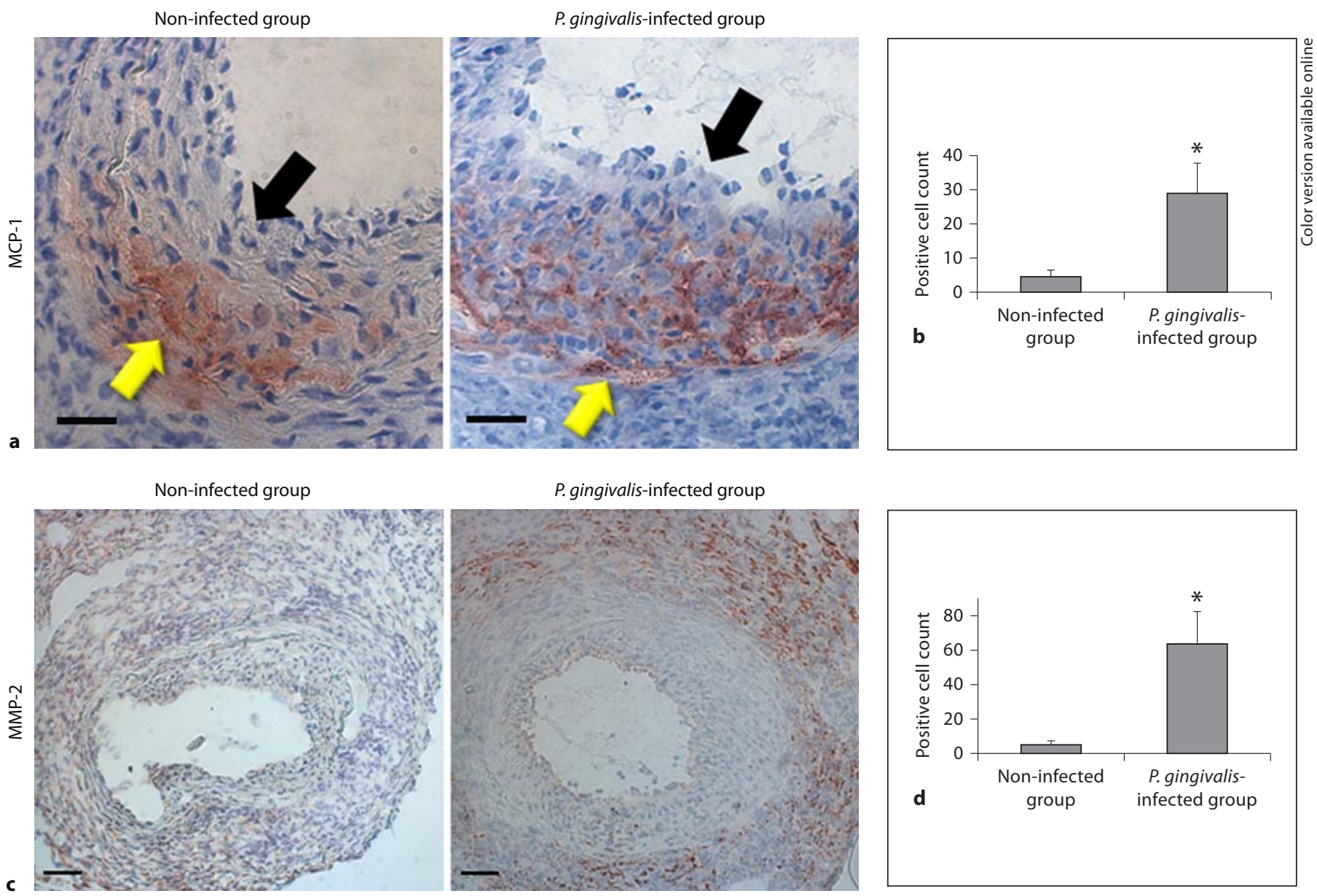

Fig. 4. $P$. gingivalis infection enhanced the expression of MCP-1 and MMP-2. a Immunohistochemical sections stained for MCP1 , showing an artery from a non-infected mouse and from a $P$. gingivalis infected mouse, respectively. Scale bars $=10 \mu \mathrm{m}$. b $P$. gingivalis infection significantly enhanced the number of MCP-1-positive cells in the neointimal area. Results are expressed as the mean \pm SEM. ${ }^{*} \mathrm{p}<0.05$. c Immunohistochemical sections stained for MMP-2, showing an artery from a non-infected mouse from a $P$. gingivalis infected mouse, respectively. Scale bars $=50$ $\mu \mathrm{m}$. d $P$. gingivalis infection significantly enhanced the number of MMP-2-positive cells in the adventitial area. Results are expressed as the mean \pm SEM. ${ }^{*} \mathrm{p}<0.05$. served in a diseased human periodontal pocket [30-32]. Our histopathological analysis revealed that the intima/ media thickness ratio in the $P$. gingivalis infected group was significantly increased in comparison to the non-infected group. There are many virulence factors of $P$. gingivalis such as lipopolysaccharides, fimbriae [33], gingipains, proteases [34] and hemagglutinin [35]. Previous studies indicated that $P$. gingivalis lipopolysaccharides trigger inflammatory pathways through the production of cytokines [36] and chemokines [37].

MCP-1 is an important factor involved in neointimal formation. Upregulation of MCP-1 gene expression after coronary angioplasty is known to result in the recruitment of monocytes and tissue macrophages to the arte- rial wall, leading to neointimal hyperplasia [38]. Additionally, treatment with a neutralizing MCP-1 antibody resulted in a significant reduction in neointimal formation in a rat model of carotid injury [39]. A previous report showed that MCP-1 expression was upregulated in $P$. gingivalis infected human umbilical vein endothelial cells [40]. Another study showed that $P$. gingivalis induced MCP-1 in an ex vivo human whole-blood model [41]. In the present study, our immunohistochemical results showed that the expression of MCP-1 in the neointimal area was enhanced in the $P$. gingivalis infected group compared to the non-infected group. Therefore, MCP-1 might play a critical role in the promotion of neointimal hyperplasia by $P$. gingivalis infection. 


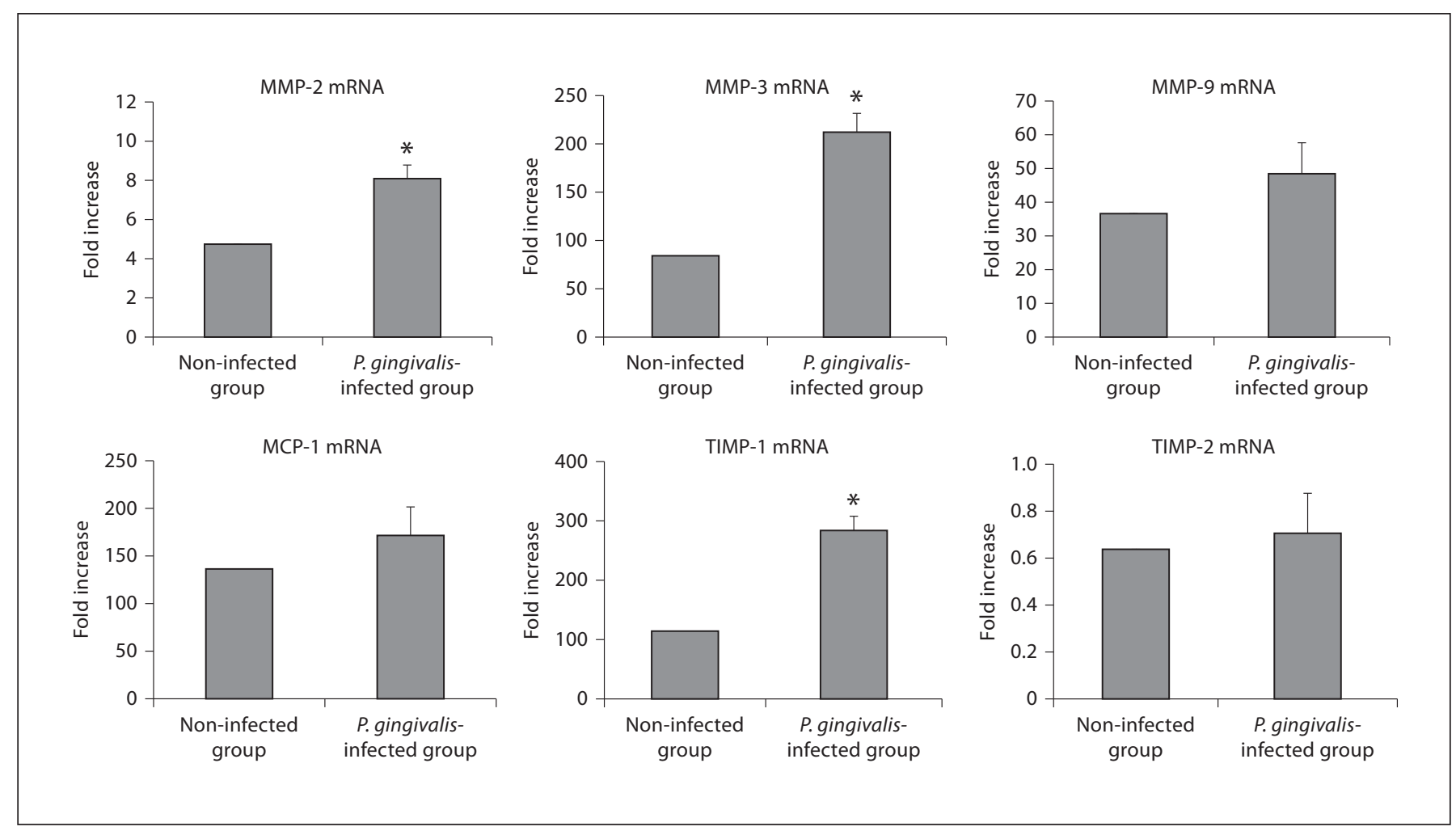

Fig. 5. Results of the RT-PCR analysis. The $P$. gingivalis infected group had elevated arterial mRNA levels of MMP-2, MMP-3 and TIMP-1 compared to the non-infection group. However, the mRNA levels of MMP-9, MCP-1 and TIMP-2 were not significantly different in the arteries from the $P$. gingivalis infected group and the non-infected group. Results are expressed as the mean \pm SEM. ${ }^{*} \mathrm{p}<0.05$.

In the injured arteries of the $P$. gingivalis infected group, the mRNA expression of MMP-2 and MMP-3 was increased compared to the injured arteries of the noninfected group. MMP-2 and MMP-3 were shown to be required for smooth muscle cell migration [42, 43]. It was also demonstrated that MMP-2 activity and protein expression increased in the injured arterial wall [44]. MMP2 [45] and MMP-3 knockout mice [43] showed reduced neointimal hyperplasia after carotid artery ligation. In clinical studies, patients with periodontitis were found to have higher levels of MMPs and TIMPs in the blood compared to healthy control $[46,47]$. We previously demonstrated that infection with $P$. gingivalis could accelerate the progression of experimental abdominal aortic aneurysm by increasing the expression of MMP-2 [22]. Another report indicated that sites with high gingival crevicular fluid levels of MMP-3 and TIMP-1 are at significantly greater risk for progression of periodontitis [48]. These findings suggest that the overexpression of
MMPs induced by $P$. gingivalis infection promotes neointimal hyperplasia.

In the present study, we showed that the infection with $P$. gingivalis enhanced neointimal formation after arterial injury in mice in association with the upregulation of inflammatory factors. Further studies will be needed to confirm our results, but periodontal treatment may become indispensable prior to balloon angioplasty and stent implantation if the existence of periodontitis promotes neointimal formation after arterial injury.

\section{Acknowledgements}

We thank Ms. Noriko Tamura and Ms. Yasuko Matsuda for their excellent technical assistance. This work was supported by a Grant-in-Aid for Scientific Research No. 21390553 and No. 23890057. 


\section{References}

$\nabla_{1}$ Gibson FC 3rd, Hong C, Chou HH, Yumoto $\mathrm{H}$, Chen J, Lien E, Wong J, Genco CA: Innate immune recognition of invasive bacteria accelerates atherosclerosis in apolipoprotein E-deficient mice. Circulation 2004; 109: 2801-2806

>2 Spahr A, Klein E, Khuseyinova N, Boeckh C, Muche R, Kunze M, Rothenbacher D, Pezeshki G, Hoffmeister A, Koenig W: Periodontal infections and coronary heart disease: role of periodontal bacteria and importance of total pathogen burden in the Coronary Event and Periodontal Disease (CORODONT) study. Arch Intern Med 2006;166:554-559.

-3 Janket SJ, Baird AE, Chuang SK, Jones JA: Meta-analysis of periodontal disease and risk of coronary heart disease and stroke. Oral Surg Oral Med Oral Pathol Oral Radiol Endod 2003;95:559-569.

4 Haraszthy VI, Zambon JJ, Trevisan M, Zeid M, Genco RJ: Identification of periodontal pathogens in atheromatous plaques. J Periodontol 2000;71:1554-1560.

$\checkmark 5$ Fiehn NE, Larsen T, Christiansen N, Holmstrup P, Schroeder TV: Identification of periodontal pathogens in atherosclerotic vessels. J Periodontol 2005;76:731-736.

-6 D’Aiuto F, Parkar M, Nibali L, Suvan J, Lessem J, Tonetti MS: Periodontal infections cause changes in traditional and novel cardiovascular risk factors: results from a randomized controlled clinical trial. Am Heart J 2006;151:977-984.

>7 Rajasuo A, Perkki K, Nyfors S, JousimiesSomer H, Meurman JH: Bacteremia following surgical dental extraction with an emphasis on anaerobic strains. J Dent Res 2004; 83:170-174.

>8 Heimdahl A, Hall G, Hedberg M, Sandberg $\mathrm{H}$, Soder PO, Tuner K, Nord CE: Detection and quantitation by lysis-filtration of bacteremia after different oral surgical procedures. J Clin Microbiol 1990;28:2205-2209.

$\checkmark 9$ Conner HD, Haberman S, Collings CK, Winford TE: Bacteremias following periodontal scaling in patients with healthy appearing gingiva. J Periodontol 1967;38:466472 .

10 Debelian GJ, Olsen I, Tronstad L: Bacteremia in conjunction with endodontic therapy. Endod Dent Traumatol 1995;11:142-149.

-11 Savarrio L, Mackenzie D, Riggio M, Saunders WP, Bagg J: Detection of bacteremias during non-surgical root canal treatment. J Dent 2005;33:293-303.

$\checkmark 12$ Tonetti MS: Periodontitis and risk for atherosclerosis: an update on intervention trials. J Clin Periodontol 2009;36(suppl 10):1519.

13 Jain A, Batista EL Jr, Serhan C, Stahl GL, Van Dyke TE: Role for periodontitis in the progression of lipid deposition in an animal model. Infect Immun 2003;71:6012-6018.
14 Yamamoto Y, Watari Y, Brydun A, Yoshizumi M, Akishita M, Horiuchi M, Chayama K, Oshima T, Ozono R: Role of the angiotensin II type 2 receptor in arterial remodeling after wire injury in mice. Hypertens Res 2008;31: 1241-1249.

15 Greenlee KJ, Corry DB, Engler DA, Matsunami RK, Tessier P, Cook RG, Werb Z, Kheradmand F: Proteomic identification of in vivo substrates for matrix metalloproteinases 2 and 9 reveals a mechanism for resolution of inflammation. J Immunol 2006;177:7312 7321.

-16 Ducharme A, Frantz S, Aikawa M, Rabkin E, Lindsey M, Rohde LE, Schoen FJ, Kelly RA, Werb Z, Libby P, Lee RT: Targeted deletion of matrix metalloproteinase- 9 attenuates left ventricular enlargement and collagen accumulation after experimental myocardial infarction. J Clin Invest 2000;106:55-62.

17 Mukherjee R, Brinsa TA, Dowdy KB, Scott AA, Baskin JM, Deschamps AM, Lowry AS Escobar GP, Lucas DG, Yarbrough WM, Zile MR, Spinale FG: Myocardial infarct expansion and matrix metalloproteinase inhibition. Circulation 2003;107:618-625.

18 Galis ZS, Sukhova GK, Lark MW, Libby P: Increased expression of matrix metalloproteinases and matrix degrading activity in vulnerable regions of human atherosclerotic plaques. J Clin Invest 1994;94:2493-2503.

19 Ogawa M, Suzuki J, Hishikari K, Takayama $\mathrm{K}$, Tanaka H, Isobe $\mathrm{M}$ : Clarithromycin attenuates acute and chronic rejection via matrix metalloproteinase suppression in murine cardiac transplantation. J Am Coll Cardiol 2008;51:1977-1985.

20 Lijnen HR, Soloway P, Collen D: Tissue inhibitor of matrix metalloproteinases-1 impairs arterial neointima formation after vascular injury in mice. Circ Res 1999;85:11861191.

21 Tavakoli S, Razavian M, Zhang J, Nie L, Marfatia R, Dobrucki LW, Sinusas AJ, Robinson S, Edwards DS, Sadeghi MM: Matrix metalloproteinase activation predicts amelioration of remodeling after dietary modification in injured arteries. Arterioscler Thromb Vasc Biol 2011;31:102-109.

-22 Aoyama N, Suzuki J, Wang D, Ogawa M, Kobayashi N, Hanatani T, Takeuchi Y, Izumi Y, Isobe M: Porphyromonas gingivalis promotes murine abdominal aortic aneurysms via matrix metalloproteinase-2 induction. J Periodontal Res 2011;46:176-183.

23 Suzuki J, Ogawa M, Muto S, Yamaguchi Y, Itai A, Isobe M: The effects of pharmacological PAI-1 inhibition on thrombus formation and neointima formation after arterial injury. Expert Opin Ther Targets 2008;12:783794.
24 Inagaki H, Suzuki J, Ogawa M, Taniyama Y, Morishita R, Isobe M: Ultrasound-microbubble-mediated NF-kappaB decoy transfection attenuates neointimal formation after arterial injury in mice. J Vasc Res 2006; 43:12-18.

$>25$ Sata M, Maejima Y, Adachi F, Fukino K, Saiura A, Sugiura S, Aoyagi T, Imai Y, Kurihara H, Kimura K, Omata M, Makuuchi M, Hirata Y, Nagai R: A mouse model of vascular injury that induces rapid onset of medial cell apoptosis followed by reproducible neointimal hyperplasia. J Mol Cell Cardiol 2000;32: 2097-2104.

26 Ogawa M, Suzuki J, Kosuge H, Takayama K, Nagai R, Isobe M: The mechanism of antiinflammatory effects of prostaglandin $\mathrm{E}_{2}$ receptor 4 activation in murine cardiac transplantation. Transplantation 2009;87:16451653.

27 Lyons SR, Griffen AL, Leys EJ: Quantitative real-time PCR for Porphyromonas gingivalis and total bacteria. J Clin Microbiol 2000;38: 2362-2365.

28 Li L, Messas E, Batista EL Jr, Levine RA, Amar $\mathrm{S}$ : Porphyromonas gingivalis infection accelerates the progression of atherosclerosis in a heterozygous apolipoprotein E-deficient murine model. Circulation 2002;105:861-867.

29 Meurman JH, Sanz M, Janket SJ: Oral health, atherosclerosis, and cardiovascular disease. Crit Rev Oral Biol Med 2004;15:403-413.

30 Houri-Haddad Y, Soskoine WA, Shapira L: Immunization to Porphyromonas gingivalis enhances the local pro-inflammatory response to subcutaneous bacterial challenge. J Clin Periodontol 2001;28:476-482.

- 31 Lin D, Smith MA, Champagne C, Elter J, Beck J, Offenbacher S: Porphyromonas gingivalis infection during pregnancy increases maternal tumor necrosis factor alpha, suppresses maternal interleukin-10, and enhances fetal growth restriction and resorption in mice. Infect Immun 2003;71:51565162.

32 Lin YY, Huang JH, Lai YY, Huang HC, Hu SW: Tissue destruction induced by Porphyromonas gingivalis infection in a mouse chamber model is associated with host tumor necrosis factor generation. Infect Immun 2005;73:7946-7952

33 Holt SC, Kesavalu L, Walker S, Genco CA: Virulence factors of Porphyromonas gingivalis. Periodontol 2000 1999;20:168-238.

34 Grenier D, La VD: Proteases of Porphyromonas gingivalis as important virulence factors in periodontal disease and potential targets for plant-derived compounds: a review article. Curr Drug Targets 2011;12:322-331.

-35 Belanger M, Kozarov E, Song H, Whitlock J, Progulske-Fox A: Both the unique and repeat regions of the Porphyromonas gingivalis hemagglutin A are involved in adhesion and invasion of host cells. Anaerobe 2011;18: $128-134$. 
>36 Zhang MZ, Li CL, Jiang YT, Jiang W, Sun Y, Shu R, Liang JP: Porphyromonas gingivalis infection accelerates intimal thickening in iliac arteries in a balloon-injured rabbit model. J Periodontol 2008;79:1192-1199.

-37 Hanazawa S, Kawata Y, Takeshita A, Kumada H, Okithu M, Tanaka S, Yamamoto Y, Masuda T, Umemoto T, Kitano S: Expression of monocyte chemoattractant protein 1 (MCP-1) in adult periodontal disease: increased monocyte chemotactic activity in crevicular fluids and induction of MCP-1 expression in gingival tissues. Infect Immun 1993;61:5219-5224

-38 Stark VK, Hoch JR, Warner TF, Hullett DA: Monocyte chemotactic protein-1 expression is associated with the development of vein graft intimal hyperplasia. Arterioscler Thromb Vasc Biol 1997; 17:1614-1621.

-39 Furukawa Y, Matsumori A, Ohashi N, Shioi T, Ono K, Harada A, Matsushima K, Sasayama S: Anti-monocyte chemoattractant protein-1/monocyte chemotactic and activating factor antibody inhibits neointimal hyperplasia in injured rat carotid arteries. Circ Res 1999;84:306-314.
40 Kang IC, Kuramitsu HK: Induction of monocyte chemoattractant protein-1 by Porphyromonas gingivalis in human endothelial cells. FEMS Immunol Med Microbiol 2002; 34:311-317.

41 Bodet C, Chandad F, Grenier D: Porphyromonas gingivalis-induced inflammatory mediator profile in an ex vivo human whole blood model. Clin Exp Immunol 2006;143. 50-57.

42 Kenagy RD, Hart CE, Stetler-Stevenson WG, Clowes AW: Primate smooth muscle cell migration from aortic explants is mediated by endogenous platelet-derived growth factor and basic fibroblast growth factor acting through matrix metalloproteinases 2 and 9 . Circulation 1997;96:3555-3560.

43 Johnson JL, Dwivedi A, Somerville M, George SJ, Newby AC: Matrix metalloproteinase (MMP)-3 activates MMP-9 mediated vascular smooth muscle cell migration and neointima formation in mice. Arterioscler Thromb Vasc Biol 2011;31:e35-e44.

44 Zou Y, Qi Y, Roztocil E, Davies MG: Patterns of gelatinase activation induced by injury in the murine femoral artery. J Surg Res 2009; 154:135-142.
45 Galis ZS, Johnson C, Godin D, Magid R, Shipley JM, Senior RM, Ivan E: Targeted disruption of the matrix metalloproteinase-9 gene impairs smooth muscle cell migration and geometrical arterial remodeling. Circ Res 2002;91:852-859.

46 Ramseier CA, Kinney JS, Herr AE, Braun T, Sugai JV, Shelburne CA, Rayburn LA, Tran HM, Singh AK, Giannobile WV: Identification of pathogen and host-response markers correlated with periodontal disease. J Periodontol 2009;80:436-446.

-47 Soder PO, Meurman JH, Jogestrand T, Nowak J, Soder B: Matrix metalloproteinase- 9 and tissue inhibitor of matrix metalloproteinase-1 in blood as markers for early atherosclerosis in subjects with chronic periodontitis. J Periodontal Res 2009;44:452458.

-48 Alpagot T, Bell C, Lundergan W, Chambers DW, Rudin R: Longitudinal evaluation of GCF MMP-3 and TIMP-1 levels as prognostic factors for progression of periodontitis. J Clin Periodontol 2001;28:353-359. 